\title{
PERLINDUNGAN ANAK TERHADAP PEMUATAN GAMBAR-GAMBAR PORNO DI MEDIA ONLINE
}

\author{
Oleh \\ Ellysabeth Chaterin Chrisninditya, Safik Faozi
}

\begin{abstract}
ABSTRAK
Anak adalah bagian yang tidak terpisahkan dari keberlangsungan hidup manusia dan keberlangsungan sebuah bangsa dan negara, setiap anak perlu mendapat kesempatan yang seluas-luasnya untuk tumbuh dan berkembang secara optimal, baik, fisik, mental maupun sosial.Dalam mengupayakan terwujudnya anak Indonesia yang berkualitas berakhlak mulia, dan sejahtera kita tertolong dengan adanya Internet.Sehingga kita juga dapat terhubung dengan pengguna internet diseluruh belahan dunia.Dampak positif yang didapat dari jaringan internet, sebagai media komunikasi, sebagai media pertukaran data dan sebagai media pencari informasi.Tetapi terdapat pula dampak negatif dari penggunaan internet seperti penipuan, perjudian, dan pornografi.Pornografi menjadi perhatian khusus karena anak-anak sekarang dapat mengakses dengan mudah karena kurangnya pengamanan terhadap situs-situs porno itu.

Dari latar belakang tersebut maka, dalam penelitian ini dirumuskan permasalahan sebagai berikut: (1) Bagaimana perlindungan anak terhadap pemuatan gambar-gambar porno di media online? (2) Apakah terdapat perlindungan khusus serta peran dari Negara atau Pemerintah untuk anak-anak dalam mengakses media online? (3) Apa saja hambatan dan penyelesaian dalam perlindungan anak terhadap pemuatan gambar-gambar porno di media online?

Metode pendekatan yang digunakan dalam penelitian ini adalah yuridis normatif.Dalam pendekatan In Concreto yaitu memberikangambaran peristiwa hukum konkrit yang terjadi serta mengkaji beberapa undang-undang yang berlaku dan membandingkan.Sedangkan analisis yang dipergunakan dalam penulisan skripsi ini kualitatif normatif.

Hasil penelitian menunjukkan (1) Orang tua yang memiliki wewenang dalam memberi batasan penggunaan gadget kepada anak. (2) Negara dan Pemerintah memberikan perlindungan khusus kepada dengan memblokir semua situs-situs porno yang ada di media online. (3) Hambatan yang timbul karena tidak dapat memblokir semua situs porno dengan mudah karena akan terjadi kerusakan dengan situs yang lain. Penyelesaian yang dilakukan dengan memasang internet sehat.
\end{abstract}

Kata Kunci : Perlindungan Anak, Pornografi, Media Online 


\section{LATAR BELAKANG}

Dalam Penjelasan atas Undang-Undang Republik Indonesia Nomor 35 Tahun 2014 tentang Perlindungan Anak secara umum dikatakan "Anak adalah bagian yang tidak terpisahkan dari keberlangsungan hidup manusia dan keberlangsungan sebuah bangsa dan negara, setiap anak perlu mendapat kesempatan yang seluas-luasnya untuk tumbuh dan berkembang secara optimal, baik, fisik, mental maupun sosial”.

Pasal 1 ayat (1) UndangUndang Nomor 35 Tahun 2014 tentang Perlindungan Anak dijelaskan bahwa : Anak adalah seseorang yang belum berusia 18 (delapan belas) tahun, termasuk anak yang masih didalam kandungan. Sehingga perlunya perlindungan terhadap anak agar mereka tetap merasa aman dan nyaman ketika berada di lingkungan hidup.

Perlindungan anak adalah segala kegiatan untuk menjamin dan melindungi anak dan hak-haknya agar tetap dapat hidup, tumbuh, berkembang, berpartisipasi, secara optimal sesuai harkat dan martabat kemanusiaan, serta mendapat perlindungan dari kekerasan dan deskriminasi. Penyelenggaraan perlindungan anak berdasarkan Pancasila dan berdasarkan UndangUndang Dasar Negara Republik Indonesia Tahun 1945 serta prinsip- prinsip dasar Konvensi Hak-Hak Anak meliputi :
a. nondiskriminasi;
b. kepentingan yang terbaik untuk anak;
c. hak untuk hidup, kelangsungan hidup, dan perkembangan; dan
d. penghargaan terhadap pendapat anak.
Perlindungan anak bertujuan untuk menjamin terpenuhinya hakhak anak agar dapat hidup, tumbuh, berkembang dan berpartisipasi secara optimal sesuai harkat dan martabat kemanusiaan, serta mendapat perlindungan dari kekerasan dan diskriminasi, demi terwujudnya anak Indonesia yang berkualitas, berakhlak mulia, dan sejahtera. ${ }^{1}$

Dalam mengupayakan terwujudnya anak Indonesia yang berkualitas berakhlak mulia, dan sejahtera kita tertolong dengan adanya Internet.Internet (kependekan dari Interconnection-Networking) adalah seluruh jaringan komputer yang saling terhubung menggunakan standart system global TCP/IP (Transmission Control Protocol/Internet Protocol) sehingga kita juga dapat terhubung dengan pengguna internet diseluruh belahan

\footnotetext{
${ }^{1}$ Taufik Mohammad, Bukamo Wenny, dan Azri Syaiful, Hukum Perlindungan Anak Dan Penghapusan Kekerasan Dalam Rumah Tangga (Jakarta: Rineka Cipta, 2014), Hal 107-108
} 
dunia $^{2}$.Terdapat dampak positif dan negatif dalam penggunaan internet dikalangan anak-anak dan orang dewasa. Dampak positif yang didapat dari jaringan Internet, sebagai media komunikasi, sebagai media pertukaran data dan sebagai media pencari informasi.Tetapi terdapat pula dampak negatif dari penggunaan Internet, penipuan, perjudian, dan pornografi.

Pornografi dalam KUHP diatur dalam Buku Kedua BAB XIV tentang Kejahatan Kesusilaan pada Pasal 281-282. Sebagaimana kita tahu Pasal 282 KUHP adalah pasal yang melarang publikasi yang bersifat porno. Pasal 282 bermaksud melindungi norma-norma sosial pada umumnya, sedangkan Pasal 533 ingin melindungi kepentingan anakanak muda yang belum dewasa. Undang-Undang Republik Indonesia Nomor 44 Tahun 2008 tentang Pornografi pada Pasal 1 ayat 1 , Pornografi adalah gambar, sketsa, ilustrasi, foto, tulisan, suara, bunyi, gambar bergerak, animasi, kartun, percakapan, gerak tubuh, atau bentuk pesan lainnya melalui berbagai bentuk media komunikasi dan/atau pertunjukan di muka umum, yang membuat kecabulan dan eksploitasi seksual yang melanggar norma kesusilaan dalam masyarakat.

Dengan adanya internet memudahkan banyak pelaku kejahatan atau jasa pornografi yang

${ }^{2}$ https://id.m.wikipedia.org/wiki/Internet, diunduh tanggal 19 maret 2017 mengunggah banyak konten-konten pornografi didalam media online. Media onlinediantaranya ;Youtube, Facebook, Intagram, dan Google. Hampir setiap hari masyarakat Indonesia menggunakan semua media online untuk mendapatkan informasi dan untuk bekerja.Salah satunya anak-anak, merupakan pengguna media online pada era modern sekarang ini.Anak-anak sekarang sudah lebih paham menggunakan Smartphone, Gadget, dan Laptop sehingga banyak kemungkinan mereka dapat mengakses media online dengan sendirinya.Berawal hanya ingin mencari gambar kartun, video kartun atau lagu anak-anak lewat Youtube. Tetapi saat mengakses youtube terdapat pula konten-konten porno yang dapat mereka akses dengan mudah karena jasa pornografi tidak memberikan pengamanan terhadap file yang mereka unggah ke media online.

Undang-Undang Republik Indonesia Nomor 19 Tahun 2016 tentang Informasi dan Transaksi Elektronik pada Pasal 27 ayat 1, Setiap Orang dengan sengaja dan tanpa hak mendistribusikan dan/atau mentransmisikan dan/atau membuat dapat diaksesnya Informasi Elektronik dan/atau Dokumen Elektronik yang memiliki muatan yang melanggar pornografi adalah perbuatan yang dilarang. Dan setiap orang yang memenuhi unsur sebagaimana dimaksud dalam pasal 
27 ayat (1) terancam dipidana dengan pidana penjara paling lama 6 (enam) tahun dan/atau denda paling banyak Rp. 1.000.000.000,00 (satu miliar rupiah) disebutkan dalam Pasal 45 ayat (1) Undang-Undang Republik Indonesia Nomor 19 Tahun 2016 tentang Informasi dan Transaksi Elektronik.

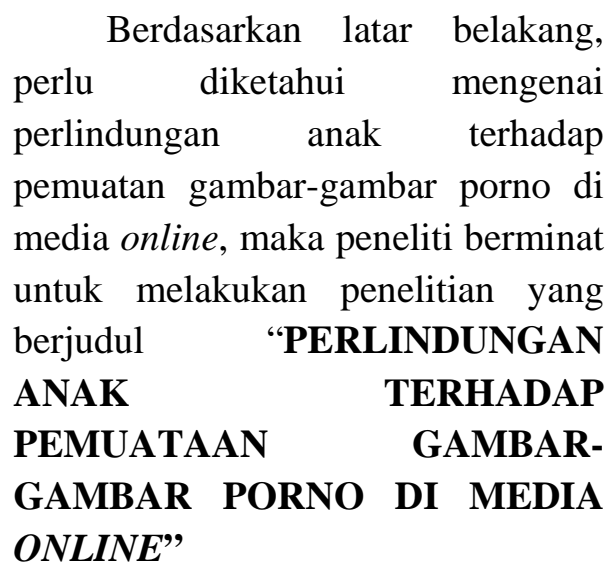

\section{TINJAUAN PUSTAKA}

\section{Tinjauan Umum Anak}

Pengertian anak menurut Pasal 1 ayat (1) Undang-Undang Nomor 35 Tahun 2014 Tentang Perlindungan anak adalah : "Seseorang yang belum berusia 18 (delapan belas) tahun, termasuk anak yang masih dalam kandungan”. Menurut Pasal tersebut anak adlah siapa saja yang belum berusia 18 tahun dan termasuk anak yang masih dalam kandungan, yang berarti segala kepentingan akan pengupayaan perlindungan terhadap anak sudah dimulai sejak anak tersebut berada di dalam kandungan hingga berusia 18 tahun.
Dalam hukum positif di Indonesia anak diartikan sebagai orang yang belum dewasa (person under age), orang yang dibawah umur/keadaan dibawah umur atau biasa disebut juga sebagai anak yang berada dibawah pengawasan wali. Pengertian anak itu sendiri jika kita tinjau lebih lanjut dari segi usia kronologis menurut hukum dapat berbeda-beda tergantung tempat, waktu dan keperluannya apa, hal ini juga akan mempengaruhi batasan yang digunakan untuk menentukan unsur anak.

Anak adalah putra kehidupan, masa depan bangsa dan negara. Oleh karena itu anak memerlukan pembinaan, bimbingan khusus agar dapat berkembang fisik, mental dan spiritualnya secara maksimal.Maka perlunya peranan orang tua, masyarakat dan Negara untuk membantu perkembangan fisik, mental dan spiritual pada anak secara maksimal.

\section{Hak-Hak Anak}

Di Indonesia perhatian dalam bidang perlindungan anak menjadi salah satu tujuan pembangunan.Hal ini dapat diketahui dalam Garis-garis Besar Haluan Negara Bab II. Disadari bahwa dalam proses pembangunan, sebagai akibat tidak adanya perlindungan terhadap anak, akan menimbulkan berbagai masalah sosial. Dalam kaitannya dengan persoalan perlindungan hukum, Undang-Undang 1945, pasal 28B 
menyatakan bahwa negara memberikan perlindungan kepada anak berhak atas perlindungan dari kekerasan dan diskriminasi.

Ketentuan Undang-Undang Dasar 1945 tersebut di atas, ditegaskan pengaturannya dengan dikeluarkannya Undang-Undang Nomor 4 Tahun 1979 tentang Kesejahteraan Anak. Pengertian kesejahteraan anak dalam UndangUndang Nomor 4 Tahun 1979 adalah anak yang dapat menjamin pertumbuhan dan perkembangan dengan wajar baik secara rahasia, jasmani maupun sosial.

Dalam pasal 2 Undang-Undang Nomor 4 Tahun 1979 merumuskan hak-hak anak sebagai berikut :

a. Anak berhak atas kesejahteraan, perawatan, asuhan dan bimbingan berdasarkan kasih sayang baik dalam keluarganya maupun di dalam asuhan khusus untuk tumbuh dan berkembang dengan wajar.

b. Anak berhak atas pelayanan untuk mengembangkan kemampuan dan kehidupan sosialnya, sesuai dengan kepribadian bangsa dan untuk menjadi warga negara yang baik dan berguna.

c. Anak berhak atas pemeliharaan dan perlindungan, baik semasa dalam kandungan maupun sesudah dilahirkan.

d. Anak berhak atas perlindungan terhadap lingkungan hidup yang dapat membahayangkan atau menghambat pertumbuhan dan perkembangan dengan wajar.

\section{Peran Pemerintah dalam Perlindungan Anak}

Peran dan
masyarakat dalamerintah pemblokiran situs porno akhir-akhir ini marak dilakukan.Bagaimana tidak, akibat dapat diaksesnya situs porno diIndonesia dampak negatiflah yang menjadi hasilnya.Dampak buruk situs porno tersebut sudah masuk dalam semua kalangan baik remaja, dewasa bahkan anakanak.Tindakan asusila yang banyak dilakukan orang tidak lepas dari akibat maraknya situs porno.Terbukti juga bahwa Indonesia paling tidak menduduki peringkat 10 besar dunia pengakses situs porno.Tentunya ini bukan prestasi membanggakan melainkan memalukan. Menyikapi kondisi Negara telah melakukan langkah pencegahan dan penanganan pornografi dengan ditandai dengan terbitnya Undang-undang Nomor 44 Tahun 2008 tentang Pornografi disusul Perpres No 25 Tahun 2012 pada 2 Maret 2012

Pengembangan Kebijakan Perlindungan Anak dalam bentuk produk politik yang penting dan sebagai wakil rakyat, anggota dewan memiliki kepentingan dalam pengembangan kebijakan yang strategis.seperti peluncuran program program-program yang menjamin perlindungan anak. Termasuk mengawasi tindakan-tindakan 
pemerintah di bidang perlindungan anak.Salah satu bentuk dukungan DPR dalam pengembangan kebijakan ini adalah memberikan apresiasi pada Rencana Menteri Pemberdayaan Perempuan dan Perlindungan Anak, Yohana Susana Yembise, menerbitkan peraturan menteri (Permen) terkait larangan anak untuk menggunakan telepon seluler (hand phone).

Dukungan ini antara lain diberikan oleh Hidayat Nurwahid, anggota Komisi VIII yang berpendapat Permen tersebut dapat menjadi instrumen dalam menyelamatkan anak dari perilaku menyimpang pornografi.

\section{Tinjauan Khusus Perlindungan Anak}

Arti perlindungan anak berdasar Undang-Undang Republik Indonesia Nomor 35 Tahun 2014 Tentang Pelindungan Anak Pasal 1 ayat (2) yaitu, segala kegiatan untuk menjamin dan melindungi anak dan hak-haknya agar dapat hidup, tumbuh berkembang dan berpartisipasi, secara optimal sesuai harkat dan martabat, kemanusiaan serta mendapat perlindungan dari kekerasan dan diskriminasi. Bentuk dari penyelenggaran perlindungan anak dijelaskan di dalam Bab IX Undang-Undang Perlindungan Anak yang mencakup dalam beberapa hal, seperti ;

a. Perlindungan Agama.Dalam hal ini bahwa setiap anak mendapat perlindungan untuk beribadah menurut agamanya dan dalam memeluk agamanya. Sebelum anak dapat menentukan pilihannya, agama yang dipeluk anak mengikuti agama orang tuanya.

b. Perlindungan Kesehatan

Bentuk perlindungan kesehatan diantaranya pemerintah wajib menyediakan fasilitas dan menyelenggarakan kegiatan atau penyuluhan supaya kesehatan yang cukup untuk anak, agar setiap anak memperoleh derajat kesehatan yang optimal sejak dalam kandungan, serta peran orang tua dan keluarga juga bertanggung jawab menjaga kesehatan anak dan merawat anak sejak dalam kandungan.

c. Perlindungan Pendidikan

Anak di dalam dan di lingkungan sekolah wajib dilindungi dari tindakan kekerasan yang dilakukan oleh guru, pengelola sekolah atau teman-teman di dalam sekolah yang bersangkutan, atau lembaga pendidikan lainnya.

d. Perlindungan Sosial

Pemerintah wajib menyelenggarakan pemeliharaan dan perawatan anak terlantar, baik dalam lembaga maupun diluar lembaga. 


\section{Pornografi}

Pornografi berasal dari kata pornoe ("prostitute atau pelacuran") dan graphein (tulisan). Dalam Encarta Referency Library dinyatakan bahwa pornografi adalah segala sesuatu yang secara material baik berupa film, surat kabar, tulisan, foto, atau lain-lainnya, menyebabkan timbulnya atau munculnya hasrathasrat seksual. Pornografi adalah penggambaran perilaku erotik dalam buku-buku, gambar-gambar, patungpatung, film, yang dapat menimbulkan nafsu atau hasrathasrat seksual, memancing birahi dan erotisme. dengan sendirinya terlibat dalam perbuatan pornografi.

Pasal 1 ayat (1) UndangUndang Nomor 44 Tahun 2008 Tentang Pornografi, yang dimaksud dengan pornografi adalah gambar, sketsa, ilustrasi, foto, tulisan, suara, bunyi, gambar bergerak, animasi, kartun, percakapan, gerak tubuh, dan bentuk pesan lainnya melalui berbagai bentuk media komunikasi dan/atau pertunjukan di muka umum, yang memuat kecabulan atau eksploitasi seksual yang melanggar norma kesusilaan dalam masyarakat.

Porno adalah segala bentuk karya manusia baik berupa cerita, gambar, film, tarian maupun lagu yang diciptakan dengan maksud sengaja untuk membakar nafsu birahi orang lain, sehingga merangsang syahwatnya dan menimbulkan pikiran-pikiran jorok dibenaknya.
Pornografi adalah ekspresi yang bersifat seksual dari kaum wanita, sedangkan erotica adalah ekspresi yang bersifat seksual yang menggambarkan atau memamerkan postur tubuh baik pada laki-laki maupun perempuan.

Dalam kamus Bahasa Indonesia, Pornografi artinya :

1. Penggambaran tingkah laku secara erotis dengan lukisan atau tulisan untuk membangkitkan nafsu berahi;

2. Bahan bacaan yang dengan sengaja dan semata-mata dirancang untuk membangkitkan nafsu berahi dalam seks.

\section{Pornografi melalui Media Online}

Pornografi di Media Online penyebaran dan muatannya melalui internet. Pornografi melalui media online termasuk kejahatan kesusilaan apabila berkaitan dengan Pasal 282 KUHP.

"Barangsiapa menyiarkan, mempertunjukan atau menempelkan di muka umum tulisan, gambaran atau benda yang telah diketahui isinya melanggar kesusilaan, atau barangsiapa dengan maksud untuk disiarkanm dipertunjukan atau ditempelkan di muka umum, membikin tulisan gambaran atau benda tersebut, memasukkannya ke dalam negeri, meneruskannya,mengeluarkannya dari negeri, atau memiliki persediaan, ataupun barangsiapa secara terang-terangan atau dengan 
mengedarkan surat tanpa diminta, menawarkannya atau menunjukkannya sebagai bisa diperoleh, diancam dengan pidana penjara paling lama satu tahun enam bulan atau pidana denda paling tinggi empat ribu lima ratus rupiah"

Pornografi tidak lepas dengan pembahasan media massa dan media online. Dalam media massa meliputi film, televisi, media cetak, koran, tabloid termasuk yang menjadi objek penelitian yang membahas pornografi. Dalam media online sekarang terdapat ; Youtube, Facebook, dan Instagaram, yang terhubung dengan koneksi internet. Media online berperan penting dalam pembentukan opini publik. Media online dapat digunakan untuk menyampaikan pesan-pesan tertentu, juga pesan-pesan dalam kaitannya dengan isu pornografi dan kebebasan berekspresi. Namum media online dan media massa juga sebagian cermin opini masyarakat.

Dalam Undang-Undang Nomor 19 Tahun 2016 Tentang Informasi Dan Transaksi Elektronik dianggap merupakan melanggar kesusilaan melalui internet diatur dalam Pasal 12 ayat (1) mengenai perbuatan yang dilarang, yaitu;

"Setiap orang dengan sengaja dan tanpa hak mendistribusikan atau mentransmisikan dan/atau membuat dapat diaksesnya Informasi Elektronik atau Dokumen Elektronik yang memiliki muatan yang melanggar kesusilaan.”

\section{METODE PENELITIAN}

\section{Tipe Penelitian}

Tipe penelitian yang digunakan oleh penulis dalam penelitian ini adalah metode penelitian YuridisNormatif. Pendekatan ini diawali dengan mengkaji berbagai undangundang tentang adanya pemuatan gambar-gambar porno di media online yang secara mudah dapat di akses oleh anak-anak. Serta menghubungkan dengan perlindungan anak terkait dengan perlindungan yang seharusnya diberikan kepada anak saat mengakses media online. Dengan penilitian ini diharapkan lebih memperkuat perlindungan anak terhadap pemuatan gambar-gambar porno di media online.

\section{Spesifikasi Penelitian}

Spesifikasi penelitian ini merupakan penelitian Yuridis Normatif yang bersifat deskriptif kualitatif, dengan pendekatan In Concreto yaitu memberikan gambaran peristiwa hukum konkrit yang terjadi tentang apa dan bagaimana perlindungan anak terhadap pemuatan gambar-gambar porno di media online

\section{Sumber Data}

Dalam penelitian ini sumber data yang diperoleh berasal dari data sekunder dalam penelitian ini dikelompokkan menjadi 3 (tiga), yaitu : 
a. Bahan Hukum Primer, yaitu bahan yang mengikat terdiri dari:

1. Undang-Undang Dasar Negara Kesatuan Republik Indonesia 1945

2. Kitab Undang-Undang Hukum Pidana

3. Undang-Undang Republik Indonesia Nomor 4 Tahun 1979 tentang Kesejahteraan Anak

4. Undang-Undang Republik Indonesia Nomor 44 Tahun 2008 Tentang Pornografi

5. Undang-Undang Republik Indonesia Nomor 35 Tahun 2014 tentang Perlindungan Anak

6. Undang-Undang Republik Indonesia Nomor 19 Tahun 2016 tentang Informasi dan Transaksi Elektronik

b. Bahan Hukum Sekunder, yaitu bahan yang member penjelasan bagi bahan hukum primer terdiri dari :

1. Buku-buku atau hasil penelitian yang membahas tentang anak, pornografi dan media online.

2. Majalah-majalah dan dokumen - dokumen yang berkaitan dengan anak, pornografi dan media online

\section{Metode Pengumpulan Data}

Dalam pengumpulan data, penulis menggunakan pengumpulan data sebagai berikut :
1. Wawancara

Wawancara adalah cara pengumpulan data dengan jalan tanya jawab sepihak yang dikerjakan secara sistematik dan berlandaskan tujuan penelitian. Wawancara yang dilakukan dengan menggunakan daftar pertanyaan, dan merupakan cara memperoleh data yang bersifat langsung.

2. Studi Pustaka

Studi pustaka merupakan metode pengumpulan data dan informasi dengan melakukan kegiatan kepustakaan melalui bukubuku, jurnal penelitian terdahulu dan lain sebagainya yang berkaitan dengan penelitian yang sedang dilakukan.

\section{Metode Penyajian Data}

Setelah data yang diperoleh terkumpul, kemudian data disusun secara teratur selanjutnya diolah dan disajikan secara ilmiah dalam bentuk uraian, tentang data yang mendukung uraian dan analisis, sedangkan data yang kurang relevan diabaikan, hal ini dimaksudkan agar data yang telah diperoleh dapat lebih mudah untuk dipahami dan dimengerti . Setelah mendapatkan berbagai data dan informasi dari sumber data yang ada, maka data tersebut akan disajikan dalam bentuk uraian keterangan secara deduktif, yaitu uraian umum 
tentang perlindungan anak terhadap pemuatan gambar-gambar porno, selanjutnya dengan data yang berkaitan dengan pemuatan gambargambar porno di media online.

\section{Metode Analisis Data}

Setelah semua data terkumpul lengkap, kemudian dianalisis menggunakan metode analisis kualitatif, data yang diperoleh dari hasil penelitian kemudian di analisis kualitatif dengan menguji data dengan konsep, teori dan peraturan perundang-undangan yang terkait untuk mencapai kejelasan mengenai pokok-pokok permasalahan . Untuk mengetahui upaya dan hambatan apa saja yang sudah dilakukan oleh Negara atau pemerintah untuk memberikan perlindungan kepada anak dalam menggunakan Gadget supaya tidak dapat mengakses gambar-gambar porno di media online. Norma, doktrin atau teori hukum yang digunakan adalah perlindungan hukum, norma hukum tentang pornografi di media online.

\section{Perlindungan Anak terhadap pemuatan gambar-gambar porno di Media Online}

Anak adalah bagian yang tidak terpisahkan dari keberlangsungan hidup manusia dan keberlangsungan sebuah bangsa dan negara, setiap anak perlu mendapat kesempatan yang seluas-luasnya untuk tumbuh dan berkembang secara optimal, baik, fisik, mental maupun sosial.
Untuk memberikan kesempatan bagi anak bertumbuh dan berkembang kita tertolong dengan adanya Internet. Melalui internet anak dapat mendapatkan informasi dengan cepat. Namun juga terdapat dampak positif dan negatif dari penggunaan internet dikalangan anak-anak.

Dampak positif, anak-anak mendapatkan informasi lebih cepat, anak dapat berbagi informasi dari negara satu dengan negara yang lain walaupun mempunyai jarak yang cukup jauh, anak mendapatkan hiburan melalui media online seperti : youtube, google, dan instagram. Terdapat pula dampak negatif dari pengunaan internet di media online, anak dapat mengakses gambargambar porno melalui media online yang mereka miliki.

Dengan adanya dampak negatif seperti ini perlunya perlindungan yang diberikan untuk anak-anak. Perlindungan anak dapat diberikan secara langsung dari orang yang terdekat dengan anak yaitu Orang Tua. Orang tua memiliki peranan yang sangat penting dalam hal ini. Anak dapat memegang gadget ketika orang tua memberikan ijin kepada anak untuk bermain gadget. Tetapi setelah itu kurangnya pendampingan yang diberikan oleh orang tua memberikan kesempatan anak untuk mencari informasi sendiri dengan mudahnya. Karena gadget tersambung dengan internet memudahkan anak mendapatkan informasi yang mereka inginkan. 
Tanggung jawab orang tua memperhatikan dan menjaga anak supaya anak tetap dalam pengawasan orang tua dalam menggunakan gadget. Karena setiap anak tetap memiliki hak-haknya untuk bertumbuh dan berkembang. Dalam Undang-undang Nomor 4 Tahun 1979 Tentang Kesejahteraan Anak Pasal 2-8 mengatur hak-hak anak atas kesejahteraan,Pasal 9 menyatakan bahwa orang tua adalah yang pertama-pertama bertanggung jawab atas kesejahteraan anak baik secara rohani, jasmani maupun sosial. Selanjutnya Pasal 10 ayat (1) mengatur, orang tua yang terbukti melalaikan tanggung jawabnya, yang mengakibatkan timbulnya hambatan dalam pertumbuhan dan perkembangan anak, dapat dicabut hak asuhnya sebagai orang tua terhadap anak. Apabila hal ini terjadi, maka ditunjuk orang atau badan sebagai wali.

Pencabutan kuasa hak asuh ini tidak menghapuskan kewajiban orang tua tersebut untuk membiayai sesuai kemampuannya penghidupan, pemeliharaan dan pendidikan anaknya. Pencabutan dan pengembalian kuasa asuh orang tua ini diterapkan dengan keputusan hakim.

Sehingga dapat disimpulkan bahwa, perlindungan anak yang paling dekat dengan anak adalah orang tua. Orang tua yang mempunyai tanggung jawab serta otoritas dalam memberikan batasan kepada anak untuk penggunaan gadget. Usia anak juga perlu diperhatikan sebelum anak berusia 14 (empat belas) tahun menurut Bill Gates tidak diperbolehkan diberikan gadget. Menurut Kitab Undangundang Hukum Pidana anak yang belum dewasa di usia 16 (enam belas) tahun tidak diperbolehkan menggunakan gadget. Untuk undangundang perlindungan anak serta pornografi di usia 18 (delapan belas) tahun anak tidak diperbolehkan menggunakan gadget.

\section{Perlindungan khusus serta perandari Negara atau Pemerintah untuk anak-anak dalam mengakses media online}

Perlindungan anak juga menjadi tanggung jawab Negara dan Pemerintah. Dalam Undang-Undang 35 Tahun 2014 pasal 22 berbunyi :

"Negara, Pemerintah, dan Pemerintah Daerah berkewajiban dan bertanggung jawab memberikan dukungan sarana, prasarana, dan ketersediaan sumber daya manusia dalam penyelenggaraan Perlindungan Anak"

Dinas Kementrian Komunikasi dan Informatika Provinsi Jawa Tengah termasuk dalam Pemerintah Daerah. Pemerintah daerah harus melaksanakan pengawasan langsung terhadap perlindungan hak anak, selain pengawasan perlindungan hak anak yang dari tanggung jawab dan kewajiban dari pemerintah daerah, pengawasan pemerintah daerah juga 
tekait dengan Undang-undang Nomor 44 Tahun 2018 Tentang Pornografi pasal 17, "Pemerintah dan Pemerintah Daerah wajib melakukan pencegahan pembuatan, penyebarluasan dan penggunaan pornografi.” Dilanjutkan dalam pasal 19, Untuk melakukan pencegahan sebagaimana dimaksud dalam pasal 17, Pemerintah Daerah berwenang :

a. Melakukan pemutusan jaringan pembuat dan penyebarluasan produk pornografi atau jasa pornografi, termasuk pemblokiran pornografi melalui internet di wilayahnya;

b. Melakukan pengawasan terhadap pembuatan, penyebarluasan, dan penggunaan pornografi di wilayahnya

c. Melakukan kerja sama dan koordinasi dengan berbagai pihak dalam pencegahan, pembuatan, penyebarluasan, dan penggunaan pornografi di wilayahnya; dan

d. Mengembangkan sistem

komunikasi,informasi, dan edukasi dalam rangka pencegahan pornografi di wilayahnya.

\section{Hambatan dan Upaya perlindungan anak terhadap pemuatan gambar-gambar porno di media online}

\section{Hambatan Perlindungan Anak}

Dalam pencegahan dan penanggulangan kejahatan pornografi, beberapa hambatan mewarnai dalam pelaksanaanya. Hal ini wajar karena setiap usaha untuk kebaikan tentu ada kendala yang menyertainya. Hambatan tersebut diantaranya adalah:

1. Rendahnya pemahaman masyarakat awam tentang bahaya jangka panjang pengaruh pornografi diusia anak.

2. Image masyarakat awam tentang pergaulan bebas antara mudamudi dianggap hal yang biasa.

3. Kurangnya kontrol orangtua terhadap tingkah laku putra putrinya, sehingga anak-anak bebas mengakses internet.

4. Kurangnya pemahaman orang tua untuk memberikan perlindungan kepada anak melalui internet sehat. Karena ada juga orang tua yang masih belum mengerti tentang bahaya penggunaan internet pada anak.

\section{Upaya Umum Perlindungan Anak}

A. Melalui Pendekatan Teknologi.

a. Menerapkan proteksi internet. Banyak sekali proteksi gratis yang bisa didownload dan diinstal ke personal computer (PC). Apabila menggunakan Microsoft Internet Explorer, bukalah fitur proteksi built-in lewat menu [Tools] [Internet Options] [Content] [Content Advisor]. Sistem content advisor akan membaca tag khusus yang ada pada sebuah halaman web, lantas akan mengiden tifikasikannya. 
b. Cari ISP (Internet Service Provider) yang aman. Di negara maju banyak ISP yang menawarkan proteksi internet, termasuk di dalamnya antivirus dan firewall. Keuntungannya adalah bisa mendapatkan perlindungan menyeluruh beserta software update secara gratis.

c. Pengaman e-mail. Saat ini banyak spammer yang selalu mengirimkan junk e-mail atau spam. Hal ini sangat berbahaya apabila isi e-mail tersebut adalah pornografi. Upaya preventif yang dapat dilakukan adalah seperti yang ditawarkan KidsCom, berupa layanan webbased email yang dijamin aman. Layanan ini akan membatasi masuknya email tak terdaftar ke account Anda.

d. Pengaman dalam PC . Hal ini dilakukan dengan menginstal software jenis web-filtering pada PC. Produk filter ini memiliki fitur yang bisa disetel, sehingga dapat menyaring situs apa yang layak dikonsumsi.

B. Pendekatan Budaya/Kultural Upaya preventif dengan pendekatan budaya/kultural pada dasarnya merupakan penanggulangan dengan cara mengetahui dan mematuhi etika dalam penggunaan internet, sehingga dapat menghindari penyalahgunaan dan dampak negatifnya. Pendekatan ini merupakan salah satu kebijakan, yang menyatakan perlunya membangun/membangkitkan kepekaan warga masyarakat dan aparat penegak hukum terhadap masalah cyberporn dan menyebarluaskan/mengajarkan etika penggunaan komputer melalui media pendidikan.

C. Pendekatan Moral/Agama

Kebijakan non penal dengan pendekatan moral/edukatif sangatlah dibutuhkan dalam penanggulangan cyberporn, bahkan dapat dikatakan bahwa pendekatan ini sangat strategis apabila pendekatan teknologi dan etika kurang efektif. Adanya penanaman pendidikan moral dan agama, pengetahuan akan dampak negatif cyberporn dan semaksimal mungkin menutup potensi untuk mengakses pornografi akan lebih dapat menumbuhkan kesadaran dari setiap orang untuk menghindari pornografi, apapun jenis dan medianya

D. Pendekatan Global

Internet sebagai ruang tanpa batas-batas teritorial antar negara di dunia (transnasional), menunjukkan bahwa dunia maya ini dalam pengaturan dan penanggulangan dampak negatifnya tidak mungkin dilakukan oleh negara secara sendiri-sendiri. Oleh karena itu diperlukan adanya pendekatan global (kerjasama Internasional). 
Upaya Khusus Perlindungan Anak

A. Pemerintah Hendaknya Konsisten terhadap peraturan dan kebijakan yang telah dibuat. Setiap peraturan maupun kebijakan yang telah dikeluarkan oleh pemerintahm untuk mengatasi maraknya penyebaran situs, video dan content berbau pornografi, semuanya adalah baik, namun dengan konsistensi yang diterapkan oleh pemerintah, maka penyebaran pornografi melalui berbagai media akan dapat diminimalkan Pemerintah juga bisa menaikkan tarif sanksi bagi yang melanggar peraturan tentang pornografi, sehingga dengan demikian masyarakat akan berpikir panjang untuk melakukan tindakan yang melanggar hukum karena sanksi yang mereka bayarkan jumlahnya besar.

B. Cyber Police. Pemerintah hendaknya membentuk sebuah unit kesatuan khusus yang menangani masalah kejahatan di dunia maya, termasuk cyber porn. Jika di dunia nyata polisi berpatroli di jalan raya, maka cyber police berpatroli di dunia maya. Unit ini berupa tenaga teknis yang dibekali oleh software khusus yang dapat mengawasi serta melindungi transaksi elektronik di internet.

C. Kerjasama Pemerintah dengan instansi-instansi dan lembaga pendidikan. Instansi-instansi dan lembaga pendidikan yang memasang wi-fi, harus dibarengi dengan pemasangan firewall, sehingga semua konten tidak dapat masuk, termasuk konten yang mengandung pornoaksi dan pornografi. Selain itu juga sering melakuakn sidak terhadap ponsel dan memberikan sanksi yang tegas dan menimbulkan efek jera.

D. Hukum Pidana secara tegas bagi yang membuat, mengakses, menyebarkan, menyiarkan, memproduksi, membuat, memperbanyak, menggandakan, menyebarluaskan, mengimpor, mengekspor, menawarkan, memperjualbelikan, menyewakan, atau menyediakan pornografi. Hal ini berkaitan dengan pasal Pasal 45 ayat (1) Undang-undang 19 Tahun 2016 tentang ITE, yaitu ancaman pidana penjara paling lama 6 (enam) tahun dan/atau denda paling banyak Rp. 1.000.000.000.00 (satu) milliar rupiah. Dan Pasal 29 Undangundang 44 Tahun 2008 yaitu pidana penjara paling singkat 6 (enam) bulan dan paling lama 12 (dua belas) tahun dan/atau pidana denda paling sedikit Rp. 250.000.000,00 (dua ratus lima puluh juta rupiah) dan paling banyak Rp. 6.000.000.000,00 (enam miliar rupiah).

E. Menutup Semua Akses Internet yang berbau Pornogarfi. 
Kesimpulan

\section{Perlindungan Anak terhadap pemuatan gambar-gambar porno di Media Online}

a. Menurut Undang-Undang

Nomor 44 Tahun 2008 tentang

Pornografi memiliki tujuan memberikan kepastian hukum dan perlindungan bagi warga Negara dari pornografi, terutama bagi anak dan perempuan.

b. Menurut Undang-Undang Nomor 35 Tahun 2014 tentang Perlindungan Anak adalah Negara, Pemerintah, Pemerintah Daerah, Masyarakat, Keluarga, dan Orang Tua atau Wali berkewajiban dan bertanggung jawab terhadap penyelenggaraan Perlindungan Anak.

Perlindungan khusus serta peran Negara atau pemerintah memberikan perlindungan anak terhadap pemuatan gambargambar porno di media online

Peran Negara dan Pemerintah dalam melakukan perlindungan dengan:

1. Pemblokiran situs-situs porno

2. Melakukan penyuluhan tentang dampak negatif dari situs-situs porno bagi anakanak

3. Serta memberikan perlindungan kepada anakanak yang telah menjadi korban pemuatan gambargambar porno di media online.
Perlindungan Khusus yang diberikan Pemerintah Daerah hanya memberikan penyuluhan dan menjalankan program dari pemerintah pusat.Serta melakukan pemblokiran situs-situs porno di media online oleh pemerintah pusat.Karena wewenang pemerintah pusat yang melakukan pemblokiran dan penutupan situs-situs porno di media online.

\section{Hambatan dan Upaya terhadap pemuatan gambar-gambar porno di Media Online}

Terdapat hambatan dalam menangani pemuatan gambargambar porno di media online :

1. Rendahnya pemahaman masyarakat awam tentang bahaya jangka panjang pengaruh pornografi diusia anak.

2. Image masyarakat awam tentang pergaulan bebas antara mudamudi dianggap hal yang biasa.

3. Kurangnya kontrol orangtua terhadap tingkah laku putra putrinya, sehingga anak-anak bebas mengakses internet.

4. Kurangnya pemahaman orang tua untuk memberikan perlindungan kepada anak melalui internet sehat. Karena ada juga orang tua yang masih belum mengerti tentang bahaya penggunaan internet pada anak.

Upaya Umum, dengan melakukan pengamanan kepada perangkat yang digunakan, misalnya ; laptop, gadget, atau komputer 
Upaya Khusus, dengan bekerja sama dengan dinas yang terkait untuk memberikan ganjaran yang tegas kepada pelaku yang mengunggah gambar-gambar porno di media online.

Saran

Berdasarkan penelitian dan pembahasan, penulis ingin menyampaikan saran sebagai berikut

a. Kepada para orang tua dan masyarakat luas pada umumnya, hendaknya semakin meningkatkan pengawasan dan kontrol terhadap anak ketika menggunakan gadget. Supaya tetap dalam pengawasan sehingga meminimalisir anak mengetahui gambar-gambar porno di media online.

b. Hendaknya Pemerintah Indonesia lewat Pemerintah Daerah atau Dinas-dinas yang terkait untuk melakukan sosialisasi mengenai perlindungan anak yang seharusnya diberikan untuk mengantisipasi agar anak tidak dapat mengakses gamabrgambar porno di media online. Serta Pemerintah tetap harus rajin dalam memantau situs-situs porno yang masih ada serta mengurangi kata-kata kunci di mesin pencaharian di internet.

c. Kepada tokoh agama dan tokoh masyarakat hendaknya semakin intensif melakukan pembinaan kepada warga masyarakat untuk dapat meminimalisasi potensi anak yang menjadi korban dari gambar-gambar porno di media online yang mungkin dapat terjadi di lingkungan masyarakat setempat.

\section{DAFTAR PUSAKA}

Buku :

Abdussalam, 2007, Hukum Perlindungan Anak, Ratu Agung, Jakarta.

Ajat Sudrajat. Pornografi dalam Perspektif Sejarah. Yogyakarta: UNY, 2006.

Junaidi Ahmad, 2012 PORNO! Feminisme, Seksualitas dan Pornografi di Media, Grasindo, Jakarta.

Romli Asep, 2012, Panduan Mengelola Online, Nuansa, Bandung.

Ronny Hanitijo, 1998, Metodologi Penelitian Hukum, Ghalia Indonesia 1998, Jakarta,

Soebagijo, 2008, Pornografi Dilarang Tapi Dicari, Gema Insani, Jakarta

Soemitro Irma Setyowati, 1990, Aspek Hukum Perlindungan Anak, Bumi Aksara, Jakarta

Taufik Mohammad, Bukamo Wenny, dan Azri Syaiful, 2014 Hukum Perlindungan Anak Dan Penghapusan Kekerasan Dalam Rumah Tangga, Rineka Cipta, Jakarta.

Tjipta Lesmana, 2005, Pornografi dalam Media Massa, Puspa Swara, Jakarta. 


\section{Peraturan Perundang-undangan :}

Undang-Undang Dasar Negara

Kesatuan Republik Indonesia 1945

Kitab Undang-Undang Hukum Pidana

Undang-Undang Republik Indonesia

Nomor 4 Tahun 1979 tentang Kesejahteraan Anak

Undang-Undang Republik Indonesia Nomor 44 Tahun 2008 Tentang Pornografi

Undang-Undang Republik Indonesia Nomor 35 Tahun 2014 tentang Perlindungan Anak

Undang-Undang Republik Indonesia Nomor 19 Tahun 2016 tentang Informasi dan Transaksi Elektronik

\section{Internet :}

https://id.m.wikipedia.org/wiki/Inter net , pada tanggal 19 Maret 2017 https://kbbi.web.id/pornografi , Kamis 23 Maret 2017

http://damianusbsi.blogspot.co.id/20 16/05/peran-pemerintah-danmasyarakat.html , Kamis 17 Mei 2017

http://www.romelteamedia.com/2014 /04/media-online-pengertiandan.html , Rabu 22 Maret 2017, https://maulandaagustinsibebek.word press.com/2012/11/08/pengaruhpornografi-pada-media/ , Selasa, 23 April 2017,

\section{Jurnal :}

Teguh Kurniawan. 2015. Peran Parlemen Dalam Perlindungan Anak. Jakarta: Jurnal Hukum. Vol. 6, No. 1 (Hal 47)

Irma Garnesia, “Artikel, Aksi Blokir Situs Oleh Pemerintah Bermanfaatkah?”, Tirto.id, 28 Agustus 2017 